\title{
DOWN PAYMENT (DP) DALAM PEMBIAYAAN MURABAHAH (Perspektif Fikih Mu'amalah)
}

\author{
Naimah \\ Fakultas Syariah dan Ekonomi Islam IAIN Antasari, Jl. Jenderal Ahmad Yani Km 4,5 Banjarmasin
}

\begin{abstract}
According to the Classical Islamic Literatures, down payment is clearly known as Urban in Arabic, or in Bahasa accepted by Panjar, which means an initial agreed contract into a transaction. Islamic Scholars arguably have different opinions in implementing down payment as a method in the transaction. There are some scholars who do not agree to put down payment as a particular way in the transaction, but others do. However, by exercising the quality of specific reasoning that is applied, and also the fact of the acceptance of the system of transaction, therefore this method of payment is generally accepted.
\end{abstract}

Abstrak: Menurut Literatur Islam klasik, uang muka atau down Payment (DP) sebenarnya dalam bahasa Arab dikenal dengan Urban, atau dalam bahasa diterima sebagai Panjar, yaitu kontrak yang disepakati di awal transaksi. Para Ulama Islam memiliki pendapat yang berbeda dalam menerapkan uang muka sebagai metode dalam transaksi. Ada beberapa ulama yang tidak setuju untuk menempatkan uang muka sebagai cara tertentu dalam transaksi dan ada juga yang menyetujuinya. Oleh karena itu, penerapan sistem pembayaran seperti ini akan memudahkan segala transaksi jual beli, sehingga metode pembayaran yang berlaku secara umum dapat diterima.

Kata Kunci: Down payment, urban, fatwa of national sharia committee, murabahah

\section{Pendahuluan}

Manusia secara fitrah hidup tidak bisa lepas dari orang lain dalam pemenuhan keperluan hidupnya. Interaksi antar individu manusia merupakan sebuah hal yang sangat penting dan mendapatkan perhatian besar dalam Islam, khususnya yang berkaitan dengan pertukaran harta (transaksi). Ini sebagaimana yang tergambar dalam al-Qur'an Surah an-Nisa ayat 29 yang artinya bahwa orangorang yang beriman jangan memakan harta sasamanya dengan jalan yang batil, kecuali dengan perniagaan yang didasarkan kepada suka sama suka. ${ }^{1}$

Seiring dengan perkembangan zaman dan kemajuan peradaban manusia, upaya transaksi ekonomi juga berjalan dinamis dan berkembang sehingga muncul persoalan-persoalan baru yang menuntut kejelasan hukumnya. Kejelasan hukum ini sangat penting bagi kaum muslimin, karena terkait dengan kehalalan dan ketidakhalalan terhadap produk yang dikonsumsinya. Persaoalan ini juga menjadi sangat penting, karena keyakinan kaum muslimin bahwa kehidupan mereka tidak hanya saat di dunia namun juga di akhirat dengan mempertanggungjawabkan apa yang teah mereka lakukan dan konsumsi selama di dunia.
Kejelasan hukum, terutama dalam muamalah sangat penting disebabkan sifat dari hukum muamalah yang fleksibel dan elastis. Secara umum, hukum muamalah tidak ada yang bersifat rigid dan pasti, karena justru akan menyusahkan kehidupan manusia itu sendiri. Oleh karena itu hukum dalam muamalah pada umumnya dibentuk dengan asasasas atau dasar umum yang memudahkan kaum muslimin membangun konstruk hukumnya sendiri sesuai dengan kondisi perekonomian di mana mereka hidup. Di antara konsep muamalah yang lahir seiring dengan perkembangan zaman adalah transaksi murabahah dengan menggunakan konsep Dawn Payment atau dalam istilah fikih dikenal dengan sebutan urban. Konsep ini dalam sebuah hadits sudah jelas dilarang, namun sebagaimana yang diuraikan di atas, dalam kemajuan teknologi dan peradaban serta sistem ekonomi saat ini, konsep tersebut perlu dilakukan pengkajian ulang yang sesuai dengan saat ini. Ini karena dalam praktiknya, konsep tersebut dapat memberikan kemudahan transaksi bagi semua pihak yang terlibat. Dari persoalan inilah, tulisan ini diangkat untuk dapat memberikan sumbangsih kejelasan hukum tentang konsep Down Payment dalam pembiayaan murabahah. 
Down Payment Dalam Pandangan Para Ulama

Down Payment (DP) merupakan praktik yang lazim dilakukan dalam sebuah transaksi dan dalam masyarakat secara umum sering disebut dengan istilah uang muka. Dalam bahasa Arab kata Down Payment atau uang muka sinonim dengan kata "urban" yang secara etimologi berarti sesuatu yang digunakan sebagai pengikat jual beli. Dalam terminologinya, jika seseorang membeli barang dagangan dan membayar sebagian harganya kepada penjul, dengan catatan jika ia mengambil barang dagangan maka ia melunasi harga barang, dan jika ia tidak mengambilnya, maka barang itu menjadi milik penjual. ${ }^{2}$

Dalam praktiknya, apabila sejumlah uang yang dibayarkan di muka oleh seseorang pembeli barang kepada si penjual, bila transaksi tersebut dilanjutkan, maka uang muka tersebut dimasukkan ke dalam harga pembayaran. Namun apabila tidak jadi atau batal, maka uang tersebut menjadi milik si penjual. Dalam bentuk praktik yang lain, apabila seseorang pembeli menyerahkan sejumlah uang dan menyatakan bahwa apabila saya ambil barang tersebut, maka ini adalah bagian dari nilai harga, apabila tidak jadi maka uang DP tersebut untukmu.

Dalam perspektif fikih, para ulama berbeda pendapat dalam status hukum praktik urban atau Down Payment (DP). Secara umum para ulama terbagi ke dalam dua pendapat yaitu pendapat pertama, para ulama yang tidak membenarkan praktik urban. Menurut pendapat mayoritas ulama yang terdiri dari pandapat Hanafiyah, Malikiyah, dan Syafiiyyah bahwa urban tidak sah.

Ada beberapa argumen yang dikemukakan para ulama yang melarang transaksi dengan urban yaitu pertama, adanya hadits yang secara jelas redaksinya melarang praktik urban. Hadits tersebut menyebutkan bahwa Nabi Saw. melarang jual beli urban. ${ }^{3}$ Walapun para ulama hadits menilai hadits ini dhaif (lemah), namun kelemahannya terletak pada sanad bukan matannya. Kedua, bahwa transaksi tersebut termasuk dalam kategori memakan harta orang lain secara batil, karena disyaratkan bagi si penjual tanpa ada kompensasinya. Padahal memakan harta orang lain adalah haram dan hal tersebut sudah ditegaskan oleh Allah dalam al-Qur'an yang artinya bahwa orang-orang yang beriman jangan saling memakan harta dengan jalan yang batil, kecuali dengan jalan

2 Abdullah bin Muhammad Ath-Thayyar dkk, Ensiklopedi Muamalah dalam Pandangan Marbab, t.tp. 2004, hlm. 42.

3 Redaksi hadits tersebut dapat dlihat dalam kitab alBuyu, bab fi al-Urban hadits Nomor 3502. Imam Malik dalam al-Muwatha': 2/609. Ahmad dalam Musnad-nya nomor 6436, dan Ibnu Majah nomor 3192. perniagaan yang berlaku secara suka sama suka. ${ }^{4}$ Ketiga, bahwa dalam transaksi urban, terdapat dua syarat yang batil yaitu syarat memberikan uang muka atau panjar dan syarat mengembalikan barang transaski dengan perkiraan salah satu pihak tidak ridha. Praktik ini dianggap sama dengan hak pilih terhadap hal yang tidak diketahui (khiyar al-majbul).

Pendapat kedua, adalah pendapat yang membolehkan. Menurut kalangan Hanabilah bahwa transaksi dengan urban dibenarkan dengan beberapa alasan pertama, bahwa hadits yang dijadikan sebagai dasar bagi para ulama yang tidak membolehkan jual beli urban adalah hadits yang lemah, sehingga tidak dapat dijadikan sandaran dalam melarang bentuk jual beli tersebut. Di samping itu ada sebuah atsar yang menceritakan bahwa Nafi bin Harits pernah membelikan sebuah bangunan penjara unutk Umar dari Shafwan bin Umayyah (dengan ketentuan) apabila Umar suka. Apabila tidak, maka Shafwan mendapatkan uang yang sekian dan sekian. Kedua, bahwa panjar atau uang muka adalah kompensasi dari penjual yang menunggu dan menyimpan barang transaksi selama beberapa waktu. Tentu saja ia akan kehilangan sebagian kesempatan berjualan. Ucapan orang yang mengatakan bahwa panjar itu telah dijadikan syarat bagi penjual tanpa ada imbalannya adalah ucapan yang tidak sah. Ketiga, bahwa tidak sah analogi atau qiyas praktik jual beli urban dengan kbiyar al-majhul, karena syarat dibolehkan adanya uang panjar adalah dibatasinya uang waktu menunggu. Dengan dibatasinya waktu pembayaran, maka analogi tersebut menjadi batal. ${ }^{5}$

Para ulama hukum Islam kontemporer memilih pandangan fukaha Hanbali dan membenarkan praktik Urban sebagai suatu yang tidak bertentangan dengan hukum Islam, dengan alasan bahwa hadits Nabi Saw. yang digunakan untuk melarang urban tidak sahih sehingga tidak bisa dijadikan bujjab. ${ }^{6}$

Beberapa KUH Perdata di Negara-negara Islam yang didasarkan kepada hukum Islam juga menjadikan pendapat Hanbali ini sebagai pegangan. Misalkan, dalam Kitab Undang-Undang Hukum Muamalat Uni Emirat Arab Pasal 148 dan Kitab Undang-Undang Hukum Perdata Irak pasal 92 ditegaskan bahwa pertama, pembayaran urban dianggap sebagai bukti bahwa akad telah final di mana tidak boleh ditarik kembali kecuali apabila ditentukan lain dalam persetujuan atau menurut

4 Redaksi Ayat tersebut dapat dibaca dalam al-Qur'an Surah An-Nisa ayat 29).

5 Ibnu Qudamah, al-Mugni, Dar al-Ihya al-Turast aTurabi, Beirut, 1405, hlm. 357-380.

6 Wahbah al-Zuhaili, al-Fiqh al-Islami wa Adillatuh,Jilid V, Dar al-Fikr, Damaskus,2005, hlm. 3435. 
adat kebiasaan. Kedua, bahwa apabila kedua belah pihak sepakat pembayaran urban adalah sebagai sanksi pemutusan akad, maka masing-masing pihak mempunyai hak menarik kembali akad. Apabila yang memutuskan akad adalah pihak yang membayar urban, ia kehilangan urban. Apabila yang memutuskan akad adalah pihak yang menerima urban, ia mengembalikan urban ditambah sebesar jumlah yang sama. ${ }^{7}$

Ketentuan ini memperlihatkan adanya dua tujuan urban yaitu pertama, urban dimaksudkan sebagai bukti untuk memperkuat akad, di mana akad tidak boleh diputuskan sebagai bukti untuk memperkuat akad di mana akad tidak boleh diputuskan secara sepihak oleh salah satu pihak selama tidak ada persetujuan atau adat kebiasaan yang menentukan lain. Kedua, urban dimaksudkan sebagai pemberian hak kepada masing-masing pihak untuk memutuskan akad secara sepihak dalam jangka waktu yang ditentukan dalam adat kebiasaan atau yang disepakati oleh para pihak sendiri dengan imbalan urban yang dibayarkan. Apabila yang memutuskan akad adalah pihak pembayar urban, maka ia kehilangan urban tersebut (sebagai kompensasi pembatalan akad) yang dalam waktu yang sama menjadi hak penerima urban. Sebaliknya, apabila pihak yang memutuskan akad adalah pihak penerima urban, ia wajib mengembalikan urban yang telah dibayar mitranya, di samping tambahan sebesar jumlah urban tersebut sebagai kompensasi kepada mitranya atas tindakannya membatalkan akad. ${ }^{8}$

Dari apa yang dikemukakan di atas tampak bahwa akad yang semula mengikat bagi kedua belah pihak berubah menjadi akad yang tidak mengikat karena adanya urban yang ditujukan untuk menjadi imbalan atas pemutusan akad secara sepihak. Dengan demikian tampak pula bahwa urban merupakan sarana melalui pemutusan akad dilakukan.

Dalam Fatwa Dewan Syariah Nasional, dikenal juga istilah urban dengan sebutan uang muka. Pembayaran uang muka ini dapat diberlakukan dalam akad pembiayaan murabahah antara sebuah Lembaga Keuangan Syariah (LKS) denngan nasabahnya. Ketentuan tersebut dapat dilihat pada angka 7 dari amar kedua Fatwa DSN yang bunyinya adalah sebagai berikut bahwa jika uang muka memakai kontrak urban sebagai alternatif uang muka maka pertama, jika nasabah memutuskan untuk membeli barang tersebut, maka nasabah

\footnotetext{
Syamsul Anwar, Hukum Perjanjian Syariah, Studi tentang Teori Akad dalam Fikih Muamalat, Raja Grafindo Persada, Jakarta, 2007, hlm. 348.

$8 \quad$ Ibid, hlm. 348-349.
}

tinggal membayar sisa harga. Kedua, jika nasabah batal membeli, uang muka menjadi milik bank maksimal sebesar kerugian yang ditanggung oleh bank akibat pembatalan tersebut, dan jika uang muka tidak mencukupi, nasabah wajib melunasi kekurangannya. ${ }^{9}$ Konsep uang muka atau urban dalam Fatwa Dewan Syariah Nasional, lebih cocok dikategorikan sebagai ganti rugi berdasarkan kesepakatan dengan pembayaran awal dari pada konsep urban yang dikenal dalam literatur fikih pada umumnya dengan alasan pertama, pemotongan urban atau uang muka oleh LKS dalam hal nasabah membatalkan akad murabahah didasarkan pada besarnya kerugian yang dialaminya, sehingga apabila urban itu lebih besar dari pada kerugian LKS, sisanya dikembalikan kepada nasabah dan apabila lebih kecil, LKS dapat meminta tambahan kekurangannya. Kedua, dalam konsiderannya, Fatwa Dewan Syariah Nasional tidak menyinggung hadits larangan urban. Ketiga, sebaliknya fatwa tersebut mengutip hadits tentang syarat perjanjian,"kaum muslimin setia kepada syaratsyarat mereka" dan hadits tengan ganti rugi, "tidak boleh merugikan diri sendiri dan tidak boleh merugikan orang lain". ${ }^{10}$

\section{Down Payment dalam Pembiayaan Murabahah}

Salah satu skim yang paling popular digunakan oleh perbankan syariah adalah skim jual beli murabahah. Transaksi murabahah ini lazim dilakukan oleh Rasulullah Saw. beserta para sahabatnya. Dalam fikih istilah murabahah diartikan sebagai bentuk jual beli tertentu ketika penjual menyatakan biaya perolehan barang, meliputi harga barang dan biaya-biaya lain yang dikeluarkan untuk memperoleh barang tersebut, dan tingkat keuntungan (margin) yang diinginkan. Tingkat keuntungan ini bisa dalam bentuk lumpsum atau porsentase tertentu dari biaya perolehan. Pembayaran bisa dilakukan secara tunai atau bisa dilakukan di kemudian hari yang disepakati bersama. Oleh karena itu, murabahah tidak dengan sendirinya mengandung konsep pembayaran tertunda (deferred payment). ${ }^{11}$

Murabahah pada awalnya merupakan konsep jual beli yang sama sekali tidak ada hubungannya dengan pembiayaan. Namun demikian bentuk jual

9 Lihat Fatwa Dewan Syariah Nasional (DSN) No. 13/DN-MUI/2000, diktum pertama dalam Himpunan Fatwa Dewan Syarian Nasional edisi revisi, DSN-MUI dan Bank Indonesia, Jakarta, hlm. 79-82.

10 Samsul Anwar, op.cit., hlm. 350-351.

11 Ascarya, Akad dan Produk Bank Syariah, Raja Grafindo Persada, Jakarta, 2011, hlm. 81-82. 
beli ini kemudian digunkan oleh perbankan syariah dengan menambah beberapa konsep lain sehingga menjadi bentuk pembiayaan dengan syarat yang benar-benar harus diperhatikan agar transaksi tersebut diterima secara syariah. ${ }^{12}$ Dalam pembiayaan ini bank sebagai pihak dana memberikan barang sesuai dengan spesifikasi yang diinginkan oleh nasabah yang membutuhkan pembiayaan, kemudian menjualnya ke nasabah tersebut dengan penambahan keuntungan tetap. Sementara itu nasabah akan mengembalikan utangnya di kemudian hari secara tunai maupun cicil.

Pembiayaan apabila dilihat dari sifat penggunaanya dibagi menjadi dua yaitu pertama pembiayaan produktif, yaitu pembiayaan yang ditujukan untuk memenuhi kebutuhan produksi dalam arti yang luas, seperti peningkatan usaha, baik usaha produksi, perdagangan maupun investasi. Kedua, pembiayaan konsumtif yaitu pembiayaan yang digunakan untuk memenuhi kebutuhan konsumsi yang akan akan habis digunakan untuk memenuhi kebutuhan. Pembiayaan murabahah, termasuk ke dalam jenis pembiayaan konsumtif tersebut.

Adanya uang muka dalam pembiayan murabahah untuk mengantisifasi resiko dalam pembiayaan yaitu resiko yang disebabkan oleh adanya kegagalan pihak lawan dalam memenuhi kewajiban. Resiko pembiayaan dapat bersumber dari berbagai aktivitas fungsional bank seperti pembiayaan (penyediaan dana), treasury dan investasi serta pembiayaan perdagangan yang tercatat dalam banking book atau trading book. Dalam bank syariah pembiayaan mencakup resiko terkait produk dan resiko terkait pembiayaan korporasi. Dalam praktiknya, pembiayaan murabahah di bank syariah, bank bukankah sebagai pihak penjual barang akan tetapi penjual jasa, sehingga produk-produk yang diminati nasabah belum dimiliki oleh pihak bank.

Dalam kondisi seperti ini digunakan sistem murababah kepada pemesan pembelian. Hal ini disebabkan bank semata-mata mengadakan barang untuk memenuhi kebutuhan nasabah yang memesannya. Ide tentang jual beli murabahah kepada pemesan pembelian berakar pada alasan mencari pembiayaan. Dalam operasi perbankan syariah, motif pemenuhan pengadaan asset atau modal kerja merupakan alasan utama yang mendorong datang ke pihak bank yang pada gilirannya pembiayaan yang diberikan akan membantu memperlancar arus kas yang bersangkutan. ${ }^{13}$

12 Ibid, hlm. 82-83.

13 Muhammad Syafi'i Antonio, Bank Syariah dari Teori ke Praktik, Gema Insani, Jakarta, 2001, hlm. 160.
Murabahah dapat dilakukan untuk pembelian secara pemesanan dan biasa disebut sebagai murabahah kepada pemesan pembelian. (KPP). Bank melakukan pembelian barang setelah ada pemesanan dari nasabah, dan dapat bersifat mengikat atau tidak mengikat nasabah untuk membeli barang yang dipesannya.

Penjual boleh meminta pembayaran uang tanda jadi atau biasa disebut uang muka ketika ijab-kabul. Hal ini sekedar menunjukkan bukti keseriusan pembeli. Uang muka inilah yang menjadi jaminan ganti rugi bila nasabah membatalkan transaksi murabahah. Dalam murabahab yang berdasarkan pesanan yang bersifat mengikat, pembeli tidak dapat membatalkan pesanannya. ${ }^{14}$

Harus dicatat bahwa kontrak murababah umumnya ditandatangani sebelum bank syariah mendapatkan barang yang dipesan oleh nasabah. Menurut kontrak, nasabahlah yang harus berhatihati dan mematuhi hukum dan aturan yang terkait dengan pengimporan barang, rasio laba dan speseifikasi yang benar. Nasabah sendiri lah yang menanggung semua tanggung jawab atas denda atau sanksi hukum yang diakibatkan dari pelanggaran hukum. Bank tidak ingin memikul tanggung jawab yang terkait dengan baran. Oleh sebab itu, segala resiko yang terkait dengan barang yang secara teoritis harus ditanggung bank, secara efketif dapat dihindari. ${ }^{15}$

Janji pemesan untuk membeli barang dalam murabahah bisa merupakan janji yang mengikat, bisa juga tidak mengikat. Pemesan tidak boleh diikat untuk memenuhi kewajiban membeli barang yang telah dipesan itu dengan alasan pembeli barang pada saat awal telah memberikan pilihan kepada pemesan untuk tetap membeli barang atau menolaknya. Penawarannya untuk nantinya tetap membeli atau menolak dilakukan karena pada saat transaksi awal orang tersebut tidak memiliki barang yang hendak dijualnya.

Dalam fikih, menjual barang yang tidak dimiliki hukumnya haram karena termasuk dalam kategori bai al-Fudbul. Konteks jual beli murababah jenis ini di mana belum ada barang berbeda dengan menjual tanpa kepemilikan barang. Oleh karena itu janji untuk membeli barang tersebut bisa mengikat kepada pemesan. Dalam hal ini nasabah terikat hukumnya dengan adanya pemesanan barang kepada bank.

Pembiayaan murababah terjadi apabila seseorang datang kepada bank syariah untuk meminjam dana guna membeli produk tertentu seperti mobil, rumah dan sejenisnya. Upaya memiliki benda yang 
dimaksud harus dilakukan melalui transaski jual beli dengan bank syariah. Dalam konteks ini bank syariah bertindak sebagai penjual dan nasabah sebagai pembeli. Jika bank memberikan pinjaman (dalam pengertian konvensional) kepada nasabah untuk membeli barang-barang yang dimaksud, pihak bank tidak boleh mengambil keuntungan dari pinjaman yang diberikan. Namun sebagai lembaga komersial yang mengharapkan keuntungan, bank syariah tidak mungkin untuk melakukannya. Oleh karena itu, akad yang dilakukan dalam bentuk jual beli, sehingga pihak bank syariah dapat mengambil keuntungan dari harga barang yang dijual dan keuntungan tersebut dibolehkan dalam hukum Islam. ${ }^{16}$

Karena bank syariah bukan lembaga penjual barang, transaksi murabahah ini diawali dengan pemesanan barang dari nasabah ke pihak bank syariah. Jika nasabah menerima permintaan pemesan suatu barang atau asset, ia harus membeli asset yang dipesan tersebut serta menyempurnakan kontrak jual beli yang sah antara dia dengan bank. Pembelian ini dianggap pelaksanaan janji yang mengikat secara hukum antara pemesan dan pembeli. Kedua belah pihak membuat sebuah kontrak jual beli. Berangkat dari sini lah pentingnya uang muka atau Down Payment sebagai tanda jadi saaat menandatangani kesepakatan awal pemesanan. ${ }^{17}$

Uang muka dalam pembiayaan murabahah adalah sebagai bentuk kehat-hatian perbankan syariah untuk meminimalkan resiko penyaluran dana kepada pihak ketiga sesuai dengan arah pengembangan konsep pengaturan yang semakin komprehensif. ${ }^{18}$ Adanya uang muka dalam pembiayan murabahah merupakan aplikasi dari manajemen resiko. Penerapan manajemen resiko dapat meningkatkan shareholder value, memberikan gambaran kepada pengelola kemungkinan kerugian di kemudian hari, meningkatkan metode dan proses pengambilan keputusan yang sistematis, yang didasarkan atas ketersediaan informasi.

Resiko merupakan suatu kejadian potensial, baik yang dapat diperkirakan maupun yang tidak dapat diperkirakan yang berdampak negatif terhadap pendapatan dan pemodalan. Resiko ini ditunjukkan oleh fakta bahwa dalam suatu kontrak murabahah, pembeli tidak bisa dipaksa untuk membeli barang yang telah dipesannya. Pembeli bisa saja berubah pikiran ketika tiba saat pengambilan barang yang dipesannya meskipun

\footnotetext{
16 Ibid.

17 Ibid, hlm. 167.

18 Ibid, hlm. 166
}

barang itu telah memenuhi semua syarat dan standar yang diminta.

Menghilangkan suatu resiko atau kemudharatan adalah suatu keniscayaan. Apalagi untuk tetap eksisnya suatu institusi yang mengakses dan melayani kepentingan publik untuk kesejahteraan dan kebahagiannya. Dalam hal ini perbankan syariah dan lembaga keuangan syaiah lainnya yang memiliki peran yang sangat urgen dan strategis bagi islamisasi ekonomi dan sarana dakwah unutk tumbuh kembangnya ekonomi Islam, bahkan diharapkan menguasai pasar gobal dengan telah teruji mampu bertahan dari krisis global bahkan sebagai solusi terbaik untuk keluar dari krisis. Pandangan ini sejalan dengan sebuah kaidah fikih yang artinya bahwa bahaya (resiko) harus dihilangkan.

Melindungi atau menghindar dari segala kerusakan sebagai bentuk maslahat merupakan aplikasi dari konsep maqashid al-Syariah untuk memenuhi kepentingan dan kebahagian umat manusia serta untuk menjaga dan atau melindungi kepentingan semua orang dari hal-hal yang tidak diinginkan. ${ }^{19}$

Uang muka yang diharamkan dalam jual beli disebabkan apabila tidak terjadi pembelian, uang muka itu hangus dan menjadi milik penjual sehingga para fukaha mengaktegorikan sebagai makan harta secara batil, gharar. Sedangkan uang muka dalam pembiayaan murabahah sebagaimana dalam Fatwa Dewan Syariah Nasional Nomor 13/DSN-MUI/IX/2000 adalah sebagai upaya antisipasi resiko/kerugian yang akan ditanggung oleh lambaga keuangan syariah, artinya uang muka tersebut tidak serta merta menjadi milik bank syariah ketika nasabah membatalkan pembelian suatu produk, tetapi tergantung kepada jumlah kerugian yang diderita oleh lembaga keuangan syariah, yaitu apabila kerugian itu lebih kecil dari uang muka, kelebihan uang muka itu kembali kepada nasabah. Sebaliknya apabila kerugian itu lebih besar dari uang muka, nasabah harus menambah dari uang muka. ${ }^{20}$

Dari penjelasan ini dapat dilihat uang muka tidak mengandung unsur memakan harta orang lain secara batil, gharar ataupun maisir. Yang ada adalah upaya saling menguntungkan kedua belah pihak dan komitmen atau muamalah atau transaski yang dilaksanakan. Inilah salah satu prinsip hukum Islam yaitu dalam transaksi muamalah tidak boleh mendatangkan kerugian bagi diri sendiri dan orang

19 Habib Nazir dan Muh. Hasanudin, Ensiklopedi Ekonomi dan Perbankan Syariah, Kaki Langit, Bandung, 2004, hlm. 20.

20 Ibid, hlm. 25. 
lain. Karena dalam konsep Islam, manusia hidup untuk mencapai falah yaitu konsep multidimensi yang memiliki implikasi pada aspek perilaku individual (mikro) dan perilaku kolektif (makro) yang lengkap dan menyeluruh (universal) bagi kehidupan manusia yang meliputi spritualitas dan moralitas termasuk di dalamnya bidang ekonomi.

Uang muka dalam pembiayaan murabahab sebagaimana dalam Fatwa Dewan Syariah Nasional Nomor 13/DSN-MUI/IX/2000, merupakan instrumen tambahan dalam akad murabahab yang dilakukan di lembaga keuangan syariah, yaitu uang muka dalam akad pembiayaan murabahah. Diperbolehkan meminta uang muka apabila kedua belah pihak sepakat dengan besaran jumlah uang muka yang ditentukan berdasarkan kesepakatan.

Dengan demikian, uang muka bukan sebagai satu syarat yang harus ada ketika berlangsungnya transaski murabahah. Tetapi sebagai syarat tambahan apabila terjadi kesepakatan antara bank dan nasabah yang menginginkan adanya uang muka. Syarat tambahan ini tidak bertentangan dengan syariah karena syarat adanya uang muka adalah perkara yang mubah dan secara urf mengandung kemaslahatan agar masing-masing pihak memiliki komitmen, serius dan bersungguh-sungguh atas transaksi yang dilaksanakan dan terhindar dari kekecewaan serta kerugian yang berakibat pada konflik dan sengketa yang mengakibatkan pudarnya persatuan dan persaudaraan.

Adanya perbedaan pendapat tentang hukum uang muka-sebagaimana yang telah penulis sebutkan pada bagian terdahulu- termasuk dalam pembiayaan murabahah adalah persoalan kbilafiyah yang semestinya tidak perlu untuk dibesarbesarkan. Persoalan kaum muslimin tidak terletak pada perbedaan masalah-masalah kbilafiyah yang didasarkan kepada ijtihad. Akan tetapi terletak pada tidak dioptimalkannya potensi akal, pembekuan fikiran, pembisuan kehendak, pemasungan kebebasan, perampasan hak asasi, pengabaian kewajiban, tersebarnya egoisme, pengabaian sunnah-sunnah Allah tentang alam dan masyarakat, kesewenangan atas kebenaran.

Perbedaan pendapat tentang uang muka ini termasuk ikbtilaf dalam lapangan fikih, karena perbedaan dalam mengambil dalil hukum yaitu beradsarkan kepada hadits Nabi Muhammad Saw. Padahal apabila dilakukan komparasi antara hadits yang melarang uang muka dan hadist yang membolehkan uang muka, maka hadits yang melarang praktik uang muka dinilai lemah dan para ulama sepakat bahwa hadist yang lemah atau dhaif tidak dapat dijadikan bujjah untuk menetapkan suatu hukum. Oleh karena itu, untuk adanya kesepakatan, mestinya dikembalikan kepada kaidah hukum yang menetapkan bahwa semua bentuk muamalah boleh dilakukan kecuali ada dalil yang mengharamkannya. ${ }^{21}$

Aspek muamalah merupakan bagian yang sangat prinsip dalam Islam, karena dengan cara bermuamalah, kehiduan manusia ditata agar tidak terjadi pengsengketaan dalam kontrak sosial atara satu pihak dengan pihak lainnya dalam masyarakat.

Pada dasarnya uang muka dalam pembiayaan murabahah dibangun atas dasar saling percaya antara nasabah dengan lembaga keuangan. Oleh karena itu istilah lain bagi pembiayaan murabahan adalah bai al-Amanah. Amanah (kepercayaan, kejujuran) merupakan hal yang abstrak, dan untuk mencapai kemaslaahtan dalam bentuk yang konkrit diwujudkan dengan uang muka sebagai pengikat amanah antara nasabah dengnan lembaga keuangan syariah. Ini sejalan dengan firman Allah yang artinya bahwa sesungguhnya Allah memerintahkan kepadamu untuk menyampaikan amanat kepada yang berhak menerimanya. ${ }^{22}$

Manusia menurut ajaran Islam adalah khalifah di muka bumi yang bertugas menata kehidupan sebaik mungkin sehingga tercipta kedamaian dalam hidup di tengah manusia yang dinamis. Dalam konteks perilaku kehidupan sehari-hari, amanah memiliki arti tumbuhnya sikap untuk memelihara dan menjaga apa saja yang menajdi perjanjian atau tanggungan manusia berupa benda nyata atau yang bersifat maknawi yang harus ditunaikan.

Amanah merupakan unsur yang sangat vital dan penting keberadaannya dalam kelangsungan roda perekonomian. Bencana terbesar di dalam pasar dewasa ini adalah meluasnya tindakan manipulasi, dusta, batil, khianat, bahkan menzalimi orang dengan perdagangan yang dilakukan. Misalnya dengan berbohong dalam mempromosikan barang (taghrir), mudah bersumpah, menimbun stok barang demi keuntungan pribadi, adanya persengkokolan jahat untuk memperdaya konsumen (tamajil), menyembunyikan kerusakan barang (tadlis) dan sebagainya. Pada hakikatnya perdaganagn tersebut disibukkan oleh keuntungan yang kecil daripada keuntungan yang besar yaitu kepada keuntungan yang fana dari pada keuntungan yang kekal.

Amanah bertambah penting pada saat seseorang memesan barang kepada pihak lain yaitu dalam bentuk murabahah kepada pemesan pembelian yang merupakan salah satu bentuk pembiayaan murabahah di perbankan syariah. Dalam hal ini, pihak yang lain percaya dan memegang janji demi kemaslahatan bersama, jika salah satu pihak

\footnotetext{
21 Ibid, hlm. 28.

22 Redaksi ayat tersebut bisa dibaca dalam al-Qur'an Surah an-Nisa ayat 58.
} 
menjalankannya hanya demi kemaslahatan atau keuntungan pihaknya tanpa memikirkan kemaslahatan atau keuntungan pihak lain, maka ia teah melakukan sebuah tindakan khianat.

Keputusan Fatwa Dewan Syariah Nasional yang menetapkan Lembaga Keuangan Syariah dibolehkan untuk meminta uang muka apabila kedua belah pihak sepakat, tidak bertentangan dengan asas-asas murabahah yang ditetapkan fukaha klasik karena situasi dan kondisi antara pelaksanaan murabahah yang dilaksanakan pada zaman dulu berbeda dengan pelaksanaan murabahah pada masa kini sebagai salah satu portofolio pembiayaan di Lembaga Keuangan Syariah.

Dalam fikih, penetapan hukum tidak terlepas dari illat, yaitu suatu yang sudah jelas dan pasti yang dapat dipergunakan dasar pembinaan dan mengikat dalam menentukan ada atau tidak nya suatu hukum. Paradigma seperti ini berangkat dari suatu keyakinan bahwa bahwa ketentuan-ketentuan yang diturunkan Allah untuk mengatur perilaku manusia memiliki alasan logis (nilai hukum) dan hikmah yang hendak dicapainya. Allah tidak menurunkan ketentuan dan aturan dengan sia-sia tanpa tujuan apa-apa. Secara umum tujuan tersebut adalah pencapaian kemaslahatan dunia dan akhirat, sedangkan secara khusus bahwa setiap perintah dan larangan mempunyai alasan logis (nilai hukum) dan tujuan masing-masing.

Adapun yang menjadi penyebab (illah) dalam menetapkan hukum dibolehkannya uang muka dalam pembiayaan murabahah adalah bermuamalah tidak secara tunai dan pembayarannya dengan sistem taqsith (angsuran). Dalam hal ini uang muka dianalogikan pada jaminan karena sebagai pengikat dan saling percaya yang ada pada dua belah pihak yang saling bermuamalah (bertransaski).

\section{Penutup}

Dari apa yang telah diuraikan di atas, maka dapat diambil kesimpuan bahwa melakukan transaksi murabahah dengan konsep Down Payment atau urban secara hukum Islam dibenarkan, karena sifat hukumnya yang khilafiyah dan tidak pasti (zhanni). Ketentuan hukum dalam khazanah fikih klasik bersifat ijtihadi, sehingga perlu konstekstualisasi hukum melalui kajian ijtihadi sehingga dapat disimpulkan bahwa dalam transaksi ekonomi saat ini, eksistensi Dawn Payment dapat memberikan kemudahan dalam transaksi perbankan saat ini. Adanya verifikasi terhadap hadits yang melarang juga dijadikan dasar tentang ketidakmutlakan hukum haram terhadap praktik urban.

\section{Daftar Rujukan}

Al-Zuhaili, Wahbah, al-Fiqh al-Islami wa Adillatuh,jiid V, Dar al-Fikr, Damaskus,2005.

Antonio, Muhammad Syafi'i, Bank Syariah dari Teori ke Praktik, Gema Insani, Jakarta, 2001.

Anwar, Syamsul, Hukum Perjanjian Syariah, Studi tentang Teori Akad dalam Fikih Muamalat, Raja Grafindo Persada, Jakarta, 2007.

Ascarya, Akad dan Produk Bank Syariah, Raja Grafindo Persada, Jakarta, 2011.

Ath-Thayyar, Abdullah bin Muhammad, dkk, Ensiklopedi Muamalah dalam Pandangan Marhab, t.p. 2004.

Fatwa Dewan Syariah Nasional (DSN) No. 13/DN-MUI/2000, diktum pertama dalam Himpunan Fatwa Dewan Syarian Nasional edisi revisi, DSN-MUI dan Bank Indonesia, Jakarta.

Nazir, Habib dan Muh. Hasanudin, Ensiklopedi Ekonomi dan Perbankan Syariah, Kaki Langit, Bandung, 2004.

Qudamah, Ibnu, al-Mugni, Dar al-Ihya al-Turast aTurabi, Beirut, 1405. 
